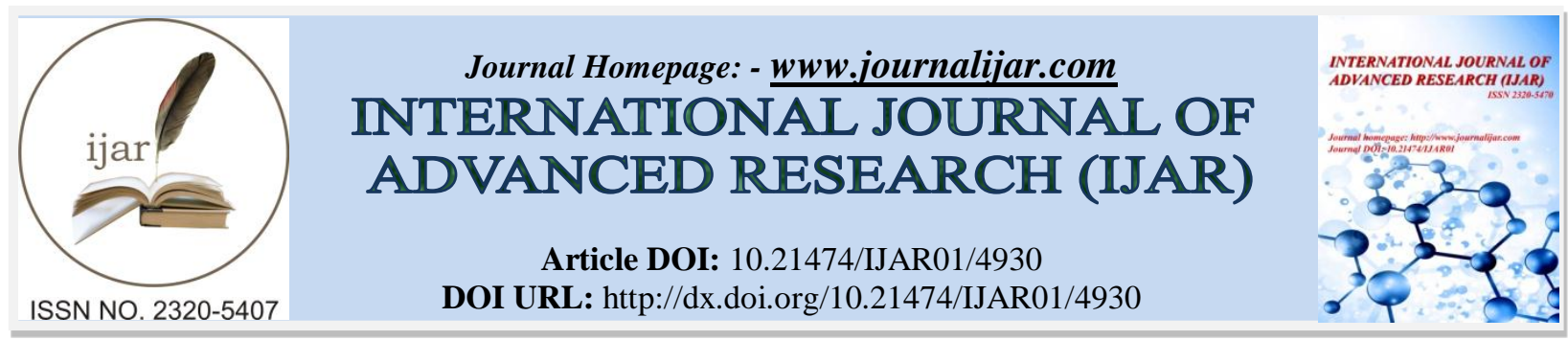

RESEARCH ARTICLE

\title{
THE ANALYSIS ON THE EFFECT OF LEADERSHIP CHARACTER ON MOTIVATION AND THE IMPACT OF MOTIVATION ON THE COMMITMENT OF SOLDIERS AT KODAM V BRAWIJAYA.
}

Abdul Hanan ${ }^{1}$, Zaenal Fanani ${ }^{2}$ and Mohammad Soleh ${ }^{2}$.

1. Students Magister Program of National Defense of Postgraduate Program Brawijaya University.

2. Lecturer Magister Program of National Defense of Postgraduate Program of Brawijaya University.

\section{Manuscript Info}

Manuscript History

Received: 23 May 2017

Final Accepted: 25 June 2017

Published: July 2017

\section{Abstract}

Leadership issue is always interesting topic. Some literatures of leadership have explained what someone must do to be a good leader. Attitude and style of leader must be set in compliance with leadership situation or precondition of a good leader. Organization may fail or success mostly because of leadership. An expression said that it was a leader who must take responsibility for the failure of certain work. It means that a leader would sit on the important position in the organization. Leader would take account for leadership. Speaking about leadership, it is like an attractive scenery for highlight. Over times, leadership is a center of human being. There is an expression that leadership has been old as human history. Leadership is needed by human because human needs a strength and wants to restrain a weakness. Leadership character can influence soldiers' performance. One factor improving soldiers' work achievement is organizational commitment. However, it is still problematic because soldiers' performance is affected by leadership character.

This research is attempting to analyze the effect of leadership character on soldiers' motivation, to examine the effect of soldiers' motivation in the environment at Kodam $\mathrm{V}$ Brawijaya on commitment, and to recognize factor with the most dominant effect on soldiers' motivation in the environment at Kodam V Brawijaya. Research lasts for 3 months from 18 January 2017 to 21 March 2017 at Kodam V Brawijaya. Type of research is survey using questionnaire. Data are processed with statistic tool. Therefore, this research applies quantitative data through Structural Equation Model with Software WarpPLS 5.0.

Result of research gives several indications. (1) Leadership character at Kodam V Brawijaya is represented by directive leadership character. It is a character in which commanders are willing to understand soldiers' aspiration; always giving direction to the soldiers; and delegating soldiers in proper manner. All of these give positive effect on soldiers' intrinsic motivation. Strong motivation from leader is indeed influential to soldiers by intrinsic or extrinsic ways. Soldiers' extrinsic motivation, related to creating conducive organizational environment, will improve soldiers' commitment through a recognition given to the soldiers for their performance. (2) The 
dominant factors influencing organizational commitment at Kodam $\mathrm{V}$ Brawijaya environment is directive leadership character, strong motivation to lead, and extrinsic motivation with conducive work environment.

Copy Right, IJAR, 2017,. All rights reserved.

\section{Introduction:-}

Background:-

Leadership is always an issue giving attractive impression. Leadership explains about how someone can be a good leader, what attitude and style that leader must consider in leadership, and also what precondition underlines a good leader. Whether organization can fail or success, it is mostly due to the effect of leadership. A noble idiom has said that leader is a person who takes responsibility for the failure of certain work. Therefore, a leader always sits on important position in the organization.

Wherever a place the leader sits upon, a leader is always charged for taking account the leadership. Talking about leadership is quite attractive from any perspectives. Leadership is a center of discussion about human being. It is said that leadership was old as human history. Leadership is needed by human to develop strength and to cover up weakness.

There are two opinions about leadership that have been conflicting to each other. One is that leader is born, while other persists that leader is formed and forged. At the first perspective, someone becomes effective leader because he is born with leadership talents. At second perspective, leadership is made and forged toward effectiveness. Taking this issue into account, experts are then producing a dichotomy about the origin of leader. The scientific paradigm for this dichotomy resides on these two extremes.

Although leadership is a learned factor, but knowledge and skill related to this leadership are under the effect of various attributes, such as culture, faith, value, ethic and character. Knowledge and skill contribute directly to leadership process. Cultural attribute shapes leadership character, especially when a leader feels his character as unique. Faith is base assumption held by someone which stating that an idea or a concept is reliable to be fought for reality.

Faith and value are internal strength that guides people. Norm, either formal or informal, is external strength. Knowledge and skill are external factors directly influencing faith and value. Value is a component of attitude that helps someone to judge and to determine proper way of action based on which alternatives would be chosen. The value of organization is affected by leadership value.

Leadership character influences performance, especially soldiers. One factor improving soldiers' achievement is organizational commitment. However, soldiers' performance is greatly affected by leadership character.

Employee's motivation and performance at work are depending on the balance between work productivity and welfare. A study about motivation is an effort to answer the problem of human complex behavior and the relationship of this problem to employee's work. In some institutions, employee's condition is varying with their capacity, their willingness to accomplish a work, and also their motivation. A leader of certain work unit or institution must have a forward-looking vision that can be used as a guide description. Such vision is needed to motivate employee. Clearly defined vision would motivate each employee. Employee is facilitated to direct their capacity and willingness toward achievement. This motivation is different based on obsession, wage, and career orientation. Indeed, leader control is needed to restrain this difference but still in compliance with the goal of organization or work unit.

Based on this overview, there is a relationship between leadership character and motivation, and the motivation has an impact on organizational commitment. The author attempts to review and analyze this issue, and to capture the result. This research is conducted on all TNI-AD soldiers at Kodam V Brawijaya.

\section{Formulation of Problem:-}

\section{Several problems are formulated:-}

1. How is the effect of leadership character on soldiers' motivation at Kodam V Brawijaya environment? 
2. How is the effect of soldiers' motivation at Kodam V Brawijaya environment?

3. What is the factor with dominant effect on soldiers' motivation at Kodam V Brawijaya environment?

\section{Objective of Research:-}

Based on problems of research, the objective of research is:-

1. To analyze the effect of leadership character on soldiers' motivation at Kodam V Brawijaya environment.

2. To examine the effect of soldiers' motivation at Kodam V Brawijaya environment.

3. To investigate the factor with dominant effect on soldiers' motivation at Kodam V Brawijaya environment.

\section{Method Of Research}

\section{Location and Time of Research:-}

Research is implemented at Kodam V Brawijaya by some reasons. This location has a problematic human resource at military context. It also has a case about leadership character and leadership style of the commanders, which would influence soldiers' commitment at Kodam V Brawijaya. Research takes a schedule of 3 months, from 18 January 2017 to 21 March 2017.

\section{Type of Research:-}

Explanatory research is chosen as research type. Survey method is therefore used, which means that this research attempts to explain the effect of leadership character on work motivation and the impact of this motivation on soldiers' commitment in the military organization. The survey is done to capture information and data relevant to this research.

\section{Type and Source of Data:-}

Two data are collected, respectively primary and secondary. Primary data are obtained from direct interview with respondents, and these are collected with questionnaire. Secondary data, as said by Emory and Cooper (1995), have two sources, internal and external. Internal data come from research object, Kodam V Brawijaya. External data derive from environment out of Kodam V Brawijaya, such as Statistical Central Bureau of Indonesia (BPS).

\section{Sampling Technique:-}

Sampling technique is total sampling because the sample involves all commanders and soldiers at Kodam V Brawijaya environment. The representative respondent is counted for 170 persons. To reduce the bias, Maholtra (1995) suggests that the sample should be set minimally 5 times of question items in the questionnaire.

\section{Sampling Method:-}

Because data are cross-sectional, sample size is then determined with Slovin Equation (Umar, 2011):

$$
\begin{aligned}
& \mathrm{n}=\mathrm{N} \\
& \multicolumn{1}{c}{1+\mathrm{N} \text { e } 2} \\
& \text { Where: } \\
& \mathrm{n}=\text { sample size (respondents) } \\
& \mathrm{N}=\text { Population Size } \\
& \text { e } 2=\text { error tolerance rate of } 10 \%
\end{aligned}
$$

Sample proportion is determined by the following equation:

$$
\begin{aligned}
& \mathrm{n}=\mathrm{-a0} \\
& \mathrm{n}=99 \text { respondents. }
\end{aligned}
$$

As shown by Slovin Equation, the obtained sample is 99 respondents.

\subsection{Data Analysis Technique}

Research model is the effect of leadership character on work motivation and the impact of this motivation on organizational commitment at Kodam V Brawijaya environment. It is shown at Figure 1. 


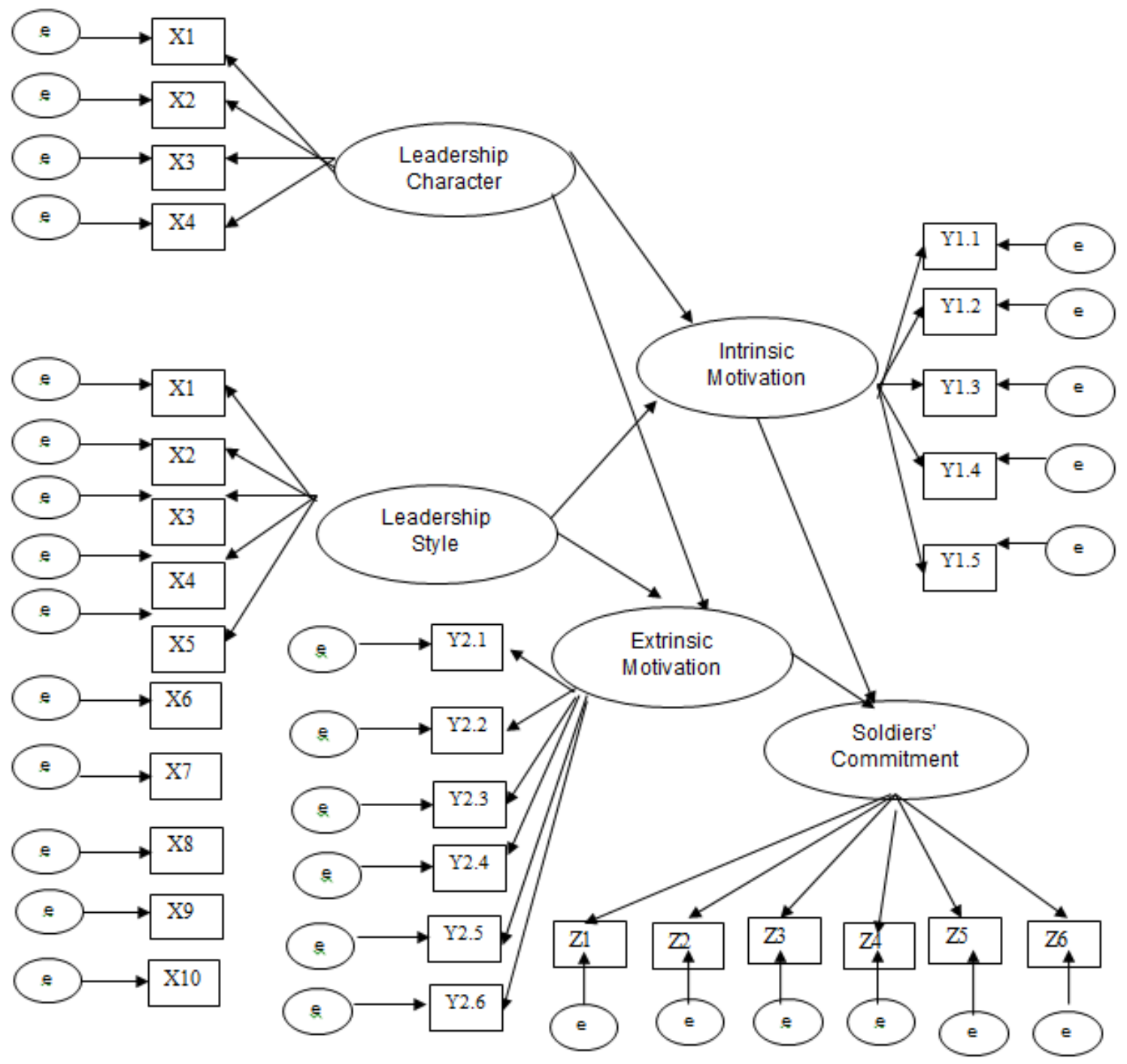

Figure 1:- SEM Analysis Model

Validity and reliability tests are done with Structural Equation Modeling (SEM) facilitated by software WarpPLS 5.0. SEM is selected because it provides direct explanation about validity and reliability tests. Whether question is valid or not is an indicator measuring latent variable. This validity measurement involves testing whether all loads are significant $(\mathrm{p}<0.05)$ by condition of $\mathrm{t}$-test greater than 1.96 . The reliability of an indicator is known by calculating composite reliability or construct reliability with the following equation (Ghozali and Fuad, 2005):

$\rho=((\Sigma \lambda) 2) /[(\Sigma \lambda) 2+\Sigma(\theta)]$

Where:

$\rho=$ composite reliability

$\lambda=$ loading indicator

$\theta=$ error variance indicator

Bagozzi and Yi (1998) in Ghozali and Fuad (2005) have suggested that out-off level is 0.6, meaning that both composite reliability or construct reliability is relatively good. Hypothesis test is one statistic method used to ensure that if $\mathrm{H} 1$ is correct, then $\mathrm{H} 0$ is wrong. Based on this test, the relationship between two variables can be understood. Hypothesis test in SEM is shown by fit index model. The tested hypothesis was:

H0: $\Sigma=\Sigma(\theta)$ against $\mathrm{H} 1: \Sigma \neq \Sigma(\theta)$ 
$\Sigma$ is a matrix of input, while $\Sigma(\theta)$ is a matrix of estimation. H0 says that matrix of estimation in SEM can better represent data properly, while H1 does suggesting the reverse. Structural Equation Modeling (SEM) is a statistic technique that can analyze latent variable, indicator variable, and direct measurement of error. Latent variable is an abstract concept that is only observable indirectly through its effect on observed variables (indicators). Indicator variable is one that can been observed or measured empirically.

\section{Result and Discussion:-}

Structural Model on The Effect of Leadership Character on Motivation and The Impact of Motivation on Organizational Commitment at Kodam V Brawijaya Environment

This structural model has used Partial Least Square. This usage represents a construct model aimed to develop a theory to further the existing model. Indeed, PLS-SEM is designed to attest predictive relationship between constructs and it is done by examining whether there is a relationship or an effect between these constructs. PLSSEM leads to a consequence, precisely that it lacks of a strong theoretical base because parameteric and nonparameteric assumptions have been thrown away. Model precision can be known from coefficient of determination (R-Square). PLS-SEM is very appropriate for research aimed to develop a theory. In SEM method, some variables are processed, such as predictor variable, response variable, and mediation variable. Mediation variable is a connecting variable between predictor variable and response variable. It changes into response variable if it is affected by predictor variable, and also changes into predictor variable if it influences response variable.

Mediator variable can be called as intervening variable because theoretically it affects the observed phenomena (endogenous variable). The process can be explained through the effect of relationship between exogenous variable and its phenomena. If exogenous variable is not influencing endogenous variable after controlling mediator variable, then there is a perfect or a complete mediation. If the effect of exogenous variable on endogenous variable declines, but still differs from 0 after controlling mediator variable, therefore, partial mediation exists (Jogiyanto and Abdillah, 2009).

WarpPLS is used as a tool to process statistic data. Why it is used is because it helps author to understand the effect of variables at certain degree of complexity because it involves few constructs and recursive indicators. Variance approach is used to keep observable the load of each item. This approach is really helpful in measuring loading value that represents latent variable. This variable would be the predictor that influences response variable. Following is a structural model describing the Effect of Leadership Character on Motivation and The Impact of Motivation on Organizational Commitment at Kodam V Brawijaya environment.

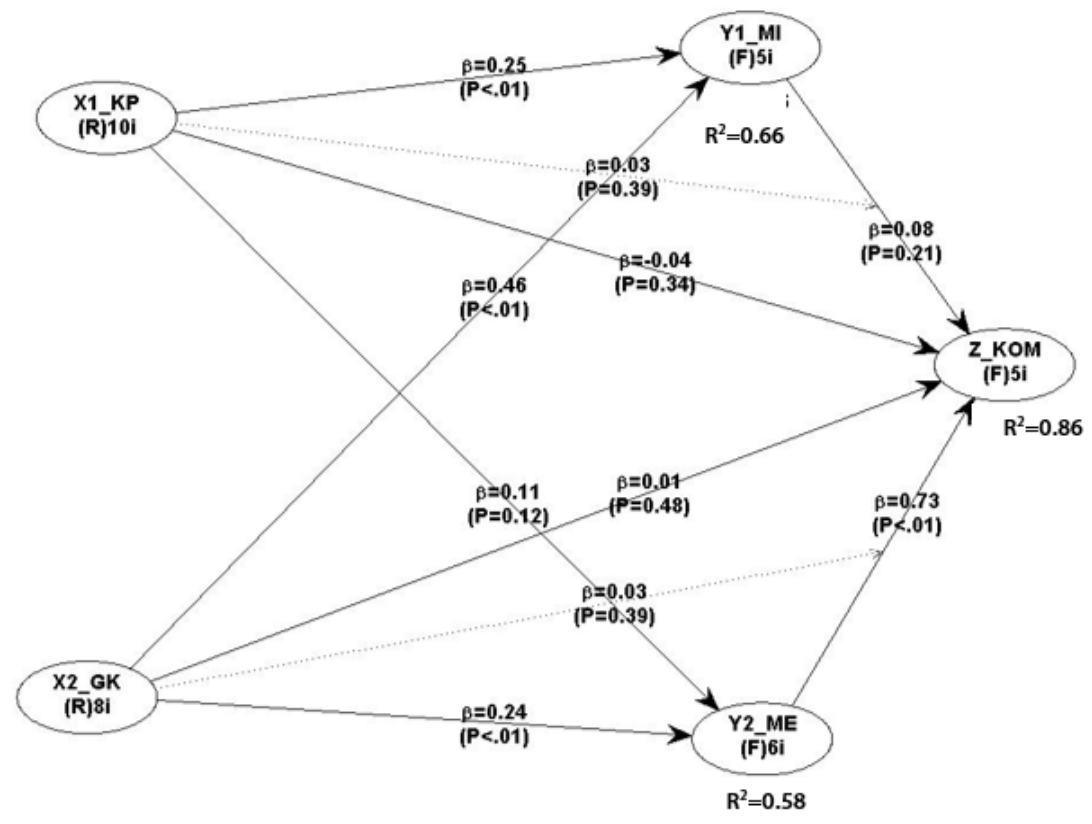

Figure 1:- Path Interpretation 


\section{Implication of Research:-}

Data analysis with WarpPLS 5.0 has given several results. Leadership character has influenced motivation. The impact of soldiers' motivation on organizational commitment is rated by $86 \%$. Leadership character is represented by directive leadership character where commanders know what soldiers want and give recognition to their soldiers. Soldiers who can perform the assignment delegated from their commanders have positive effect on intrinsic motivation with beta coefficient of 0.249 . The increase of directive leadership characteristic would improve intrinsic soldiers' motivation by 0.249 .

Leadership style represented by a strong interest or motivation of the commanders to become a leader has a positive effect by beta coefficient at 0.455 on the intrinsic motivation of soldiers, which is related with the opportunity of soldiers to develop their military career. The increase by 1 unit in leadership style, where the commanders are strongly motivated to become a leader, would increase soldiers' intrinsic motivation to 0.455 .

Moreover, leadership style represented by a strong interest or motivation of the commanders to become a leader has a positive effect by beta coefficient at 0.238 on the extrinsic motivation of soldiers, which is related with the security at work environment. Therefore, the increase by 1 unit in leadership style through strongly motivated commanders to become leader, will increase extrinsic motivation of soldiers to 0.238 .

Conducive work environment may support commanders' motivation. Extrinsic motivation, represented by work security, has a positive effect by beta coefficient rate of 0.726 on organizational commitment. Work recognition is given based on the achievement of soldiers. It means that the more conducive is work environment, the greater is soldiers' commitment to work environment, which increases to 0.726 .

\section{Conclusion And Suggestion:-}

Pursuant to the result and discussion, few conclusions are provided.

\section{Conclusion:-}

1. The characteristic of Kodam V Brawijaya leaders is represented by directive leadership character. It is a character in which commanders are willing to understand soldiers' aspiration; always giving direction to the soldiers; and delegating soldiers in proper manner. Such leadership character has a positive effect on soldiers' intrinsic motivation. Strong motivation from leader will affect soldiers in intrinsic or extrinsic ways.

2. Soldiers' extrinsic motivation, related to creating conducive organizational environment, will improve soldiers' commitment through a recognition given to the soldiers for their performance.

3. The dominant factors influencing organizational commitment at Kodam V Brawijaya environment is directive leadership character, strong motivation to lead, and extrinsic motivation with conducive work environment.

\section{Suggestion:-}

\section{Several suggestions are given as following:}

1. Soldiers' commitment at Kodam V Brawijaya environment must be set to optimum. Soldiers' motivation can be increased by subjecting them to a training, giving them incentive, and recognizing their existence with clear career path. The motivation with the most dominant effect on soldiers' commitment is extrinsic motivation.

2. Conducive work environment will provide the condition of openness for leader to produce recognition based on soldiers' performance. 


\section{References:-}

1. Aurik Gustomo dan Anita Silvianita, 2011. Pengaruh Nilai-Nilai Personal, Gaya Kepemimpinan dan Budaya Organisasi terhadap Kepuasan Kerja Karyawan. Makalah Kelompok Keahlian Manajemen Manusia dan Kewirausahaan Sekolah Bisnis dan Manajemen Institut Teknologi Bandung

2. Barkdoll, Gerald R. (2007). "Individual Personality and Organizational Culture Or Let's Change this Place so I Feel More Comfortable.” Diakses dari http://www.pamij.com tanggal 3 Oktober 2007.

3. Chen, L.Y. (2004). "Examining the Effect of Organization Culture and Leadership Behaviors on Organizational Commitment, Job Satisfaction and Job Performance at Small and Middle-sized Firms of Taiwan", The Journal of American Academy of Business, Cambrige, pp. 432-438 (September, 2004).

4. Eliason, B. Clair MD; Clare Guse, MS; Mark S. Gottlieb, PhD. Arch Fam Med. 2000;9:228- 2. Personal Values of Family Physicians, Practice Satisfaction, and Service to the Underserved. Vol. 9 No. 3, March 2000.

5. Franz, Cheryl. (2004). "A Cross-Cultural Study of Employee Empowerment and Organizational Justice". Dissertation at Wayne State University. Detroit, Michigan.

6. Hartmann, L. C., \& Bambacas, M. (2000). Organizational commitment: A multi method scale analysis and test of effects. International Journal of Organization Analysis, 8(1), 89-108. Retrieved December 22, 2005, fiom ProQuest database.

7. Maharaj, I \& Schlechter, A (2007). "Meaning in Life and Meaning of Work : Relationship with Citizenship Behavior, Commitment and Job satisfaction". Management Dynamics, Vol. 16, No.3, 2007.

8. Malhotra, N., \& Mukherjee, A. (2004). The relative influence of organizational commitment and job satisfaction on service equality of customer-contact employees in banking call centers. The Journal of Services Marketing, 18(2/3), 162-174. Retrieved May 22, 2006, fiom ProQuest database.

9. Markovich, Y, Davis, A.J, Dick, R.V (2007). "Organizational Commitment Profiles and Job Satisfaction among Greek Private and Public Sector Employees". International Journal of Cross Cultural Management, Vol.7 No 1, 2007, pp. $77-99$.

10. Mosadeghrad and Yarmohammadian, (2006). "A Study of Relationship between Manager's Leadership Style and Employees' Job Satisfaction", Leadership in Health Service, Vol.19, No.2, pp. xi-xxviii.

11. Markovich, Y, Davis, A.J, Dick, R.V (2007). "Organizational Commitment Profiles and Job Satisfaction among Greek Private and Public Sector Employees". International Journal of Cross Cultural Management, Vol.7 No 1, 2007, pp. $77-99$.

12. Mosadeghrad and Yarmohammadian, (2006). "A Study of Relationship between Manager's Leadership Style and Employees' Job Satisfaction", Leadership in Health Service, Vol.19, No.2, pp. xi-xxviii.

13. Hofstede, G. (1983). "The Cultural Relativity of Organizational Practices and Theories", Journal of International Business Studies, Vol. 14, pp. 75-89 (Fall, 1983).

14. Koesmono, H. (2007). "Pengaruh Kepemimpinan dan Tuntutan Tugas terhadap Komitmen Organisasi dengan Variabel Moderasi Motivasi Perawat Rumah Sakit Swasta Surabaya", Jurnal Manajemen dan Kewirausahaan, Vol.9, No.1, hal. 30-40.

15. Mosadeghrad and Yarmohammadian, (2006). "A Study of Relationship between Manager's Leadership Style and Employees' Job Satisfaction", Leadership in Health Service, Vol.19, No.2, pp. xi-xxviii.

16. Moustofa, Karen South. (2004). "A Cross-Cultural Investigation of Temporal Orientation in Work Organization: A Differentiation Matching Approach”. Dissertation at University of Memphis.

17. Sekaran, Uma (2003), Research Methods For Business: A Skill Building Approach, John Wiley and Sons, Inc, Fourth Edition. 